\title{
Gastrointestinalis manifesztációk monogénes primer immundefektusokban
}

\author{
Veres Gábor dr. - Gaál Zsuzsanna dr. \\ Debreceni Egyetem, Általános Orvostudományi Kar, Gyermekgyógyászati Klinika, Debrecen
}

\begin{abstract}
A 6 éves életkor előtt kialakuló, úgynevezett nagyon korai kezdetú gyulladásos bélbetegség a Crohn-betegségtől és a colitis ulcerosától eltérő etiológiájú, de szintén krónikus bélrendszeri gyulladással járó kórkép. Döntően monogénes eredetú immundefektusnak kell tartanunk, amelyben a bélrendszeri tünetek mellett az immundeficientiákra jellemző tünetek változatos formában jelentkezhetnek. A háttérben áló géndefektusok meghatározásának jövője várhatóan az új generációs szekvenálási technológia, azonban a genetikai meghatározottság mellett szem elótt kell tartanunk azt is, hogy a génállomány a környezeti hatásokkal folyamatos kölcsönhatásban áll. Az utóbbiak közül a táplálkozás feltétlenül kiemelendő. A jövőben a gyermekkorban manifesztálódó gyulladásos bélbetegségekre jellemző, környezeti tényezők által indukált epigenetikai változások azonosítására szintén törekednünk kell. A betegség lehetô legkorábbi felismerése kulcsfontosságú, hiszen ez teszi lehetővé az adekvát kezelés megkezdését, monogénes immundefektusban a csontvelö-transzplantáció mielőbbi elvégzését.
\end{abstract}

Orv Hetil. 2018; 159(49): 2050-2056.

Kulcsszavak: monogénes immundefektusok, gastrointestinalis manifesztációk, VEO-IBD-immunológia, genetika, epigenetika

\section{Gastrointestinal manifestations in immunodeficiencies with monogenic origin}

Although very early onset inflammatory bowel disease that develops in early childhood (before the age of 6 years) has a different etiology from Crohn's disease and ulcerative colitis, it is also characterized by chronic inflammation of the gastrointestinal tract. Basically, very early onset inflammatory bowel disease should be considered as an immunodeficiency with monogenic origin where both gastrointestinal manifestations and symptoms of immunodeficiencies may develop in variable combinations. However, in the future, the evaluation of genetic alterations in the background of the disease will probably be performed by next-generation sequencing technology; one should also consider that the sequence of the DNA stands in continuous interaction with a wide variety of environmental effects, among which nutrition should be emphasized by all means. Epigenetic alterations that are induced by environmental factors, could contribute to the pathogenesis of inflammatory bowel diseases that develop during childhood, therefore, they should also be identified during further research. It has a key significance to establish the diagnosis of very early onset inflammatory bowel disease as early as possible, because this could give the opportunity to start the adequate treatment which is bone marrow transplantation in the case of monogenic immunodeficiencies.

Keywords: immunodeficiency with monogenic origin, gastrointestinal manifestations, VEO-IBD immunology, genetics, epigenetics

Veres G, Gaál Zs. [Gastrointestinal manifestations in immunodeficiencies with monogenic origin]. Orv Hetil. 2018; 159(49): 2050-2056.

(Beérkezett: 2018. augusztus 9.; elfogadva: 2018. szeptember 3.)

\section{Rövidítések}

BTK = Bruton-féle tirozin-kináz; CD = Crohn-betegség; CGD $=$ (chronic granulomatous disease) krónikus granulomatosus betegség; CVID = (common variable immunodeficiency) variábilis immunhiány; HUPIR = $($ Hungarian Pediatric IBD Reg- ister) Magyar Gyermek IBD Regiszter; IBD = (inflammatory bowel disease) gyulladásos bélbetegség; IBD-I = IBD indeterminate) indeterminált colitis; LRBA = (lipopolysaccharide-responsive beige-like anchor) lipopoliszacharidreszponzív bézsszerü horgonyfehérje; NADPH = (nicotinamide adenine di- 
nucleotide phosphate) nikotinamid-adenin-dinukleotid-foszfát; RNS $=$ ribonukleinsav; SCID $=$ (severe combined immunode ficiency) súlyos kombinált immundefektus; UC = (ulcerative colitis) colitis ulcerosa; VEO-IBD = (very early onset inflammatory bowel disease) 6 éves életkor előtt kezdődő IBD

Szervezetünk legnagyobb immunszerve maga a gastrointestinalis traktus, ezért érthetô, hogy az immunrendszer kóros múködésének számos gasztroenterológiai kórkép patogenezisében van fontos szerepe. A gastrointestinalis immunrendszernek alapvetően kettős feladatot kell ellátnia: egyrészt pédelmi vonalat biztosítani a kórokozókkal szemben, másrészt az idegen táplálékfehérjékkel toleránsnak lenni. Érdekes adat, hogy míg 10 „darab” Shigella képes véres dizentériát okozni, addig $10^{14}$ baktériummal (tízszer több, mint testünk sejtjeinek száma) békésen együtt tudunk élni [1].

Bár a Crohn-betegség (CD) lényegesen gyakoribb, és patomechanizmusának szintén döntő tényezői az immunregulációs zavarok, a jelen közleményben a nagyon gyakran monogénes immundefektussal társuló, kora gyermekkorban kezdődő gyulladásos bélbetegséget, a VEO-IBD-t emeljük ki (very early onset inflammatory bowel disease).

\section{Epidemiológia}

A gyermekkori Crohn-betegség (CD) incidenciája fokozatosan növekszik; a CD incidenciája egyre több felmérésben meghaladja a colitis ulcerosáét (UC) [2]. Hazai, prospektív, az egész országra kiterjedő epidemiológiai adatok is ezt erősítik meg [3]. Gyermek IBD Regiszterünk (HUPIR) 2007 januárjában indult, s jelenleg már közel 2000 IBD-s gyermek adatait tartalmazza. Regiszterünk alapján megállapítható, hogy a gyermekkori $C D$ incidenciája 100000 gyermekre 5,42, az UC-é 2,43 és az indeterminált colitisé (IBD-I: IBD indeterminate) 0,45 . Szomorú adat, hogy a HUPIR adatai alapján évente hazánkban kb. 5\%-kal nöpekszik a gyermekkori IBD incidenciája. Összességében a hazai incidencia hasonló a Nyugat-Európában mért magasabb értékekhez.

A gyermekkori IBD-s esetek száma az IBD-s betegek összesített számának körülbelül a 20-25\%-a, ezen belül a VEO-IBD csupán néhány százalék, de ennek incidenciája szintén folyamatosan növekszik [4]. Az egyik legmagasabb értéket Kanadában észlelték $(9,68 / 100000$ gyermek), és bár ennek pontos magyarázata nem ismert, mégis joggal feltételezhetjük, hogy az egyént az élet korai szakaszában érô környezeti hatásoknak a szerepe kiemelkedő [5]. A környezeti tényezők közül kétségkívül az egyik legfontosabb a gyermek táplálása, tehát a káros táplálék-összetevők feltehetôen fontos szerepet játszanak a betegség kialakulásában. Az IBD incidenciáját városi, illetve vidéki környezetben élő gyermekek körében öszszehasonlítva kanadai kutatók azt találták, hogy vidéki környezetben szignifikánsan alacsonyabb gyakorisággal fordul elő az IBD. Az összefüggés pedig annál kifejezettebb, minél fiatalabb a gyermek, ennek megfelelően a legnagyobb különbséget az 5 év alatti korcsoportban tapasztalták [6].

\section{Nagyon korai kezdetú IBD (VEO-IBD)}

A 6 éves életkor elótt kezdődő IBD (very early onset inflammatory bowel disease, VEO-IBD) különös diagnosztikus és terápiás nehézséggel jár. Enyhébb esetben anyatejjel táplált csecsemő haematochesiájának hátterében - infekció kizárása után - a legtöbbször először még multiplex allergiás colitist, eosinophil colitist véleményeznek, s csak a terápia sikertelensége, majd a hosszabb távú nyomon követés vezet a helyes diagnózishoz. A differenciáldiagnosztikában felmerülő gyakoribb betegségeket az 1. táblázat foglalja össze. Újabban a VEO-IBD-s csoportba sorolt betegek életkora 2 évről 6 évre emelkedett, de ez teljesen önkényesen választott életkor, hiszen ennél késóbb is megszülethet a diagnózis.

1. táblázat $\mid$ A VEO-IBD differenciáldiagnosztikájában szereplő gyakoribb betegségek

\begin{tabular}{ll}
\hline Multiplex allergiás colitis, eosinophil colitis & \\
\hline Infekció & \\
& $C M V$ \\
& Clostridium difficile \\
& Entamoeba histolytica \\
& TBC \\
\hline
\end{tabular}

Immundeficientia (ID)

- Congenitalis, monogénes ID

IL10/IL10 receptor

NCF2

XIAP

$L R B A$

TTC7

Egyéb

- Szerzett ID

Krónikus granulomatosus betegség (CGD)

Glycogenosis Ib típusa

$\mathrm{CMV}=$ cytomegalovírus; $\mathrm{ID}=$ immundeficientia $;$ LRBA = lipopolisza charidreszponzív bézsszerú horgonyfehérje; NCF2 = neutrophil cytosolicus faktor- $2 ; \mathrm{TBC}=$ tuberkulózis; TTC7 = tetratrikopeptidismétlo"déseket tartalmazó domén-7; XIAP = X-hez kötött apoptózisinhibitor

A VEO-IBD önálló entitásként való megkülönböztetését a „klasszikus” IBD-től az indokolja, hogy jelentős részük primer immunbiányos kórkép monogénes eredettel, melyek terápiája általában a csontveló-transzplantáció.

A serdülő- vagy felnőttkori kezdetű IBD-vel szemben a VEO-IBD kezdetben gyakran csak a colont érinti [4]. A háttérben álló genetikai okok ugyanakkor befolyásol- 
ják az egyes bélszakaszok érintettségének valószínűségét, NOD2-mutációnál például gyakoribb ileumérintettséget és következményesen nagyobb sebészeti beavatkozási igényt figyeltek meg [7]. A monogénes formák az egyéb társuló immunológiai rendellenességek függvényében változatos tünetekkel járhatnak, melyek egyben felhívhatják a figyelmet a VEO-IBD fokozott kockázatára. A betegség gyakran, mintegy 25\%-ban társul immundeficientiával [4]. A korai felismerés tehát a tartós tünetmentesség elérése, illetve a testi és szellemi fejlődéshez szükséges feltételek biztosítása mellett az esetlegesen társuló immundeficientia és az egyéb immunológiai rendellenességek, valamint az azokból fakadóan nagyobb gyakorisággal előforduló malignus betegségek, például a lymphomák idóben történő felismerése szempontjából is nagyon fontos.

\section{Monogénes defektusok VEO-IBD-ben}

VEO-IBD-ben gyakoribb a pozitív családi anamnézis, ami arra utal, hogy a későbbi életkorban manifesztálódó formákkal szemben a genetikai prediszpozíció szerepe hangsúlyosabb, ezzel szemben a serdülő- és felnőttkori kezdetú IBD-ben a környezeti tényezők szerepét tartják jelentősebbnek [4]. Ez logikus, hiszen az örökítőanyag szekvenciája kezdettől fogva „adott”, a környezeti tényező́k viszont - minél több idô telt el a születés óta, azaz minél magasabb az életkor, annál - több epigenetikai változás indukciójáért felelősek.

Összességében a klasszikus IBD-t poligénes meghatározottságú betegségnek tartják, amelyben az életkor fordítottan arányos a monogénes meghatározottság valószínúségével, ennek megfelelően VEO-IBD-ben a serdülő- és felnőttkori formákhoz képest döntően a monogénes formával találkozunk [8]. A monogénes formák az intestinalis immunhomeosztázis változatos zavarait idézhetik elő: okozhatják a barrierfunkció károsodását, a neutrophil granulocyták és egyéb phagocyták, illetve a T- és B-lymphocyták diszfunkcióját, társulhatnak hyperés autoinflammatiós szindrómákkal, immundeficientiával és az antiinflammatoricus szabályozómechanizmusok károsodásával [8].

A genetikai tényezók közül fontos kiemelni az ILIOR mutációját, melynek következtében nem tud érvényesülni az antiinflammatoricus ILl0-citokin hatása, így az intestinalis mucosa súlyos, krónikus gyulladása alakul ki [4]. Az IL10-szignalizáció zavarainak hátterében ugyanakkor nemcsak az ILIOR mutációja, hanem az IL10 vagy az ILIOR gének kifejeződésének hibás szabályozása is állhat [8].

A CD patogenezisében igazoltan fontos szerepet betöltő NOD2-fehérje polyubiquitinatiójáért felelős enzimet kódoló TRIM22-gén („tripartite” motívumot tartalmazó gén-22) variánsait a közelmúltban azonosították VEO-IBD-ben [9].

A cytoskeleton organizációját és az epithelsejtek polarizációját szabályozó RhoA jelátviteli útvonallal kölcsön- ható TTC7-gén (tetratrikopeptidismétlődéseket tartalmazó domén-7) mutációja multiplex intestinalis atresiával, illetve kombinált immundefektussal (SCID) társulhat $[8,10]$. Az IKBKG-gén $\mathrm{NF} \kappa \mathrm{B}$ (nukleárisfaktor-kappa-B)-kináz-inhibitor-mutációja, mely X-hez kötött ectodermalis dysplasiához és immundeficientiához vezet, szintén az intestinalis mucosa barrierfunkciójának károsodását okozza [8].

A NADPH-oxidáz enzimrendszer komponenseit érintô mutációk ( NCFI/2, CYBA, CYBB) a neutrophil granulocyták és egyéb phagocyták funkciózavarát idézhetik elö, és fokozott prediszpozíciót jelentenek gyulladásos bélbetegség kialakulására $[7,8]$. Krónikus granulomatosus betegségben (CGD) például az esetek $40 \%$-ában jelentkeznek IBD-szerú tünetek [8]. A phagocytasejtek funkciózavarát nemcsak mutációk, hanem a GM-CSF ellen termelődő autoantitestek is előidézhetik [7].

B- és T-sejt-defektusok szintén társulhatnak VEOIBD-vel. Ezekre példa a BTK-defektus (Bruton-féle tirozin-kináz) által okozott agammaglobulinaemia, illetve az LRBA-gén (lipopoliszacharidreszponzív bézsszerü horgonyfehérjét kódoló gén) mutációja, amely a variábilis immundeficientia (CVID) ritka, monogénes formájához vezet, és amelyre a CTLA4 csökkent expressziója jellemző a T-sejtek felszínén $[4,8]$.

A hyper- és autoinflammatiós szindrómák közül az XIAP-gén (X-hez kötött apoptózisinhibitor) mutációjával társuló, X-hez kötött lymphoproliferativ szindrómában az esetek 20\%-ában jelentkeznek CD-re jellemző tünetek és bélrendszeri elváltozások [8].

A bél bacterialis kolonizációját szabályozó fukoziltranszferáz-2-t kódoló FUT2-gén variánsai a mikrobiomban előidézett változások révén egyaránt hajlamosíthatnak CD és nekrotizáló enterocolitis kialakulására [7].

\section{VEO-IBD és epigenetika}

A monogénes formák hátterében álló genetikai eltérések mellett a jövőben törekednünk kell a VEO-IBD-re jellemző epigenetikai változások azonosítására is, hiszen alkalmazhatók lehetnek a differenciáldiagnosztikában, a prognózis és a kezelésre adott válasz előrejelzésében, illetve új terápiás célpontokat szolgáltathatnak. Vizsgálni szükséges, hogy a DNS metilációért/hidroximetilációért, illetve hisztonmódosításokért felelős enzimek közül melyeknek van szerepük a VEO-IBD patogenezisében, illetve melyek gátlószerei lehetnek sikerrel alkalmazhatók a terápiában. A mikro-RNS-ek az IBD patogenezisében igazoltan szerepet játszanak, ami nem meglepő, hiszen közülük sok részt vesz a veleszületett és az adaptív immunválasz szabályozásában, kölcsönhatásban állnak a NOD2-fehérjével és a Toll-szerú receptorokkal, illetve szabályozzák a $\mathrm{T}_{\mathrm{H}} 1, \mathrm{~T}_{\mathrm{H}} 2$ és $\mathrm{T}_{\mathrm{H}} 17$ sejtek differenciációját [11]. Míg colitis ulcerosa (UC) és CD esetén sajátosan megváltozott mikro-RNS-expressziós mintázatokat azonosítottak, addig VEO-IBD-ben jelenleg nem ismert ilyen. A társuló immunológiai rendellenességek gyakori- 
sága miatt különösen fontos lenne a malignus betegség kialakulásának fokozott kockázatát jelző biomarkerek azonosítása.

Speciális helyzetet teremt, hogy bár a mucosalis immunrendszer legfontosabb strukturális komponensei már születéskor jelen vannak, azok funkcionális érése egészen a serdülőkorig nem tekinthető befejezettnek [7]. A mucosalis humoralis immunválasz 5-6 éves korra, míg a T-sejtek által közvetített cellularis immunválasz 10-12 éves korra éri el a felnőttkorra jellemzó érettséget. A pubertás alatt bekövetkező hormonális változások szintén befolyásolják az immunrendszer múködését [7]. A VEO-IBD tehát még éretlen mucosalis immunitással rendelkező bélrendszert támad meg.

2 éves életkor előtt tehát mind az „egészséges” bélrendszer, mind az abban krónikus gyulladást fenntartó etiológiai tényezők különböznek, ezért a terápia szükségszerüen sajátos szemléletet igényel. A VEO-IBD lehető legkorábbi felismerése és diagnózisa teremti meg a lehetőséget az adekvát, egyénre szabott kezelés minél hamarabb történő megkezdésére.

\section{Crohn-betegség}

A Crohn-betegség a gastrointestinalis rendszer bármely részének fekélyes, krónikus gyulladása. Multifaktoriális kórkép, melynek pontos etiológiája a mai napig nem tisztázott. Rizikótényező a korai (2 év alatti) antibiotikumterápia, illetve a rövidebb idejű anyatejes táplálás. A leginkább elfogadott hipotézis szerint a CD olyan immunmediált betegségnek tekintendő, amely genetikai tényezőkből adódóan fogékony egyedekben alakul ki, környezeti triggerfaktorok, leginkább a kóros táplálékösszetevők hatására [12].

\section{Az immunregulációs zavarok jelentősége a Crohn-betegség patogenezisében}

Az immunológiai szabályozás zavarainak központi szerepét tükrözi, hogy a rendelkezésre álló célzott terápiás szerek nagy többsége az immunsejtek múködését és citokintermelését befolyásolja, sokszor az IL23-IL17 útvonalra kifejtett hatás révén. Az IL23 a proinflammatoricus citokinek szintjének tartós megemelkedéséhez a $\mathrm{T}_{\mathrm{H}} 17$ sejtek differenciációjának és IL17-produkciójának, valamint a macrophagok ILl-, IL6- és TNF $\alpha$-termelésének parakrin stimulációjával járul hozzá [13]. Ezen hatások ellensúlyozását szolgálja az anti-TNF $\alpha$ - (infliximab, adalimumab, certolizumab), anti-ILl - (anakinra), anti-IL6(tokilizumab), anti-IL17A- (szekukinumab), anti-IL17RA- (brodalumab), illetve az IL12 és IL23 közös p40-es alegységét célzó monoclonalis antitest (usztekinumab) $[13,14]$. A vedolizumab a leukocyták endothelhez történő kötődését és extravasatióját gátló, az a $4 \beta 7$ integrinhez kapcsolódó monoclonalis antitest [14]. Szintén az immunregulációs zavarok jelentőségét tá- masztja alá, hogy genomszintű asszociációs vizsgálatok (GWAS) keretében a több mint 200, IBD-vel asszociált locus közül a CD-re hajlamosító egyik fó genetikai eltérésnek a NOD2-gén (nukleotidkötő oligomerizációs domént tartalmazó gén-2) defektusa bizonyult [15, 16]. A NOD2 cytosolicus mintázatfelismerő receptorként (PRR) funkcionál, melynek defektusai többek között az intracellularis baktériumok elleni immunválasz, az antimikrobiális peptidprodukció és az antigénprezentáció zavaraihoz, továbbá a Paneth-sejtek funkciójának károsodásához vezetnek [12]. A NOD2 mellett a polimorfizmusok által leggyakrabban érintett gének többsége vagy az autofágiában (ATGI6L1, IRGM), vagy az endoplazmatikus stresszre adott válaszban tölt be fontos szerepet (XBP1, AGR2), számos további pedig az IL23-IL17 útvonal tagjaként (IL12B, IL23R, JAK2, STAT3, CCR6) az intestinalis mucosa krónikus gyulladásának fenntartásához járul hozzá [12, 15].

\section{Szempontok a gyermekkori IBD és VEO-IBD diagnosztikájához és kezeléséhez}

A betegséget bizonyító kizárólagos módszer, pathognomicus jellemző nincs, a diagnózist a klinikai, endoszkópos, képalkotó, laboratóriumi és szövettani adatok együttes értékelése alapján, nemritkán csak hosszabb megfigyelési idő után mondhatjuk ki. A neutrophil sejtekből felszabaduló kalprotektin székletben kimutatott szintje gyermekkori CD-ben és UC-ben is nagy gyakorlati jelentőséggel bír [17].

A monogénes formákban általában gastrointestinalis (véres széklet, hasmenés, súlyállás) vagy perianalis (fistula) tünettel jelentkezik a kórkép; ritkábban fordul elö, hogy a súlyos immunhiány következtében kialakuló fertőzések miatt fordulnak orvoshoz [18]. Fontos szem előtt tartanunk, hogy a VEO-IBD gyakran rezisztens az IBD-ben alkalmazott standard gyulladáscsökkentő és immunmodulációs terápiával szemben, ugyanakkor a háttérben álló molekuláris genetikai eltérések meghatározása célzott kezelést tehet lehetôvé, például funkcionális IL10-receptor hiányában az allogéncsontvelő- vagy -őssejt-transzplantáció kuratív megoldást jelent $[4,8]$. $L R B A$-mutáció esetén az abatacept alkalmazása eredményezett drámai javulást, míg NCF2-mutáció esetén antibiotikumkezelést követően tapasztaltak kedvező terápiás választ $[4,7]$.

\section{Következtetés}

A 6 éves életkor előtt kialakuló VEO-IBD a CD-től és UC-től eltérő etiológiájú, de szintén krónikus bélrendszeri gyulladással járó kórkép, amelyet döntően monogénes evedetü immundefektusnak kell tartanunk, és amelyben a bélrendszeri tünetek mellett az immundeficientiákra jellemző tünetek változatos formában jelentkez- 
hetnek. A betegség lehető legkorábbi felismerése kulcsfontosságú, hiszen ez teszi lehetővé az adekvát kezelés megkezdését, monogénes immunhiányban a csontvelőtranszplantáció, illetve a perifériásőssejt-transzplantáció mielőbbi elvégzését. Megjegyezzük, hogy gyermekkori kezdetü, terápiarezisztens Crohn-betegségben már sor került hazánkban autológ haemopoeticus őssejt transzplantációjára, egy 15 éves fiúgyermekben, 2014-ben [19].

A VEO-IBD gyanúja esetén elvégzendő vizsgálatokat, illetve azon belül a szükséges immungenetikai vizsgálatokat a 2. és a 3. táblázatban foglaltuk össze.

A háttérben álló géndefektusok azonosításának jövője várhatóan az új generációs szekvenálási technológia, azonban a genetikai meghatározottság mellett szem előtt kell tartanunk azt is, hogy a génállomány a környezeti hatásokkal folyamatos kölcsönhatásban áll. Az utóbbiak közül a táplálkozás feltétlenül kiemelendő, hiszen a mikrobiom összetételére és az immunsejtek múködésére egyaránt kihat, ezáltal pedig a bélrendszeri immunhomeosztázis fenntartásában nélkülözhetetlen szerepet tölt be.
A jövőben a környezeti tényezők által indukált, IBDre és VEO-IBD-re jellemző epigenetikai változások azonosítására szintén törekednünk kell. Az epigenetikai változások révén a génexpressziós mintázat a DNS szekvenciájának változása nélkül módosul, azaz ugyanaz az örökítőanyag az eltérő környezeti hatások révén máshogy „programozódik”. Mivel mind a DNS-metilációban, mind az egyes hisztonmarkerek és nemkódoló RNS-ek szintjében bekövetkező változások reverzibilisek, a beavatkozás lehetősége a genetikai eltérésekhez képest alapvetően különbözik. A mikro-RNS-ek az immunrendszer szabályozásában és az IBD patogenezisében igazoltan szerepet játszanak. Expressziós szintjük meghatározása segítheti a differenciáldiagnózist, illetve a prognózis és a kezelésre adott válasz előrejelzése révén az elérhető terápiás modalitások közötti választást. Terápiás célból expressziós szintjük szintetikus oligonukleotidok segítségével egyaránt növelhető vagy csökkenthető [20].

A Crohn-betegség jelenleg nem gyógyítható, krónikus gyulladásos bélbetegség, amelynek incidenciája sajnála-

2. táblázat | Kivizsgálási algoritmus VEO-IBD gyanújakor

\begin{tabular}{|c|c|}
\hline \multicolumn{2}{|l|}{ Egyéni anamnézis } \\
\hline & $\begin{array}{l}\text { Életkor, súlygyarapodás, infekciók, perianalis } \\
\text { betegség, endokrinológiai rendellenesség, } \\
\text { immunhiány, autoimmun betegség, malignitás }\end{array}$ \\
\hline \multicolumn{2}{|l|}{ Családi anamnézis } \\
\hline & $\begin{array}{l}\text { Különös tekintettel az IBD, immundeficientia, } \\
\text { valamint autoimmun és hematológiai kórképek } \\
\text { előfordulására }\end{array}$ \\
\hline \multicolumn{2}{|l|}{ Fizikális vizsgálat } \\
\hline & $\begin{array}{l}\text { A bőr, fogazat és haj állapota, testösszetétel, súly- és } \\
\text { hosszpercentilis meghatározás, BMI }\end{array}$ \\
\hline Laboratóriumi vizsgálatok & $\begin{array}{l}\text { Vérkép } \\
\text { Lymphocyta-alosztályok (Th1, Th2, Th17, Treg) } \\
\text { CRP, transzaminázok, vesefunkció, ASO } \\
\text { Immunglobulinok szintje (IgGl-4, IgA, IgM) } \\
\text { Székletkalprotektin } \\
\text { Rutin-vizeletvizsgálat }\end{array}$ \\
\hline \multicolumn{2}{|l|}{ Mikrobiológiai vizsgálatok } \\
\hline & $\begin{array}{l}\text { Szerológia } \\
\text { Egyéb mikrobiológiai tesztek }\end{array}$ \\
\hline \multicolumn{2}{|l|}{ Eszközös vizsgálatok } \\
\hline & Alsó és felső endoszkópia \\
\hline
\end{tabular}

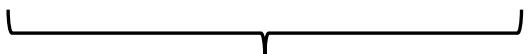

Bélrendszeri gyulladás egyéb okainak kizárása (például allergiás colitis)

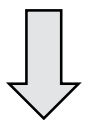

Genetikai és epigenetikai eltérések meghatározása

ASO $=$ antisztreptolizin $\mathrm{O} ; \mathrm{CRP}=\mathrm{C}$-reaktív protein $\mathrm{IBD}=$ gyulladásos bélbetegség $; \mathrm{Ig}=$ immunglobulin 


\begin{tabular}{|c|c|}
\hline $\begin{array}{l}\text { Mintázatfelismerő receptor vagy } \\
\text { azt szabályozó molekula }\end{array}$ & NOD2, TRIM22 \\
\hline $\begin{array}{l}\text { Antiinflammatoricus citokin vagy } \\
\text { receptora }\end{array}$ & IL10R \\
\hline $\begin{array}{l}\text { A veleszületett immunitás } \\
\text { zavaraiért felelős egyéb gének }\end{array}$ & $\begin{array}{l}\text { CARD9, CXCR4, IKBKG, } \\
\text { IL17F, IL17RA, IRAK4, } \\
\text { MyD88, STAT1, TRAF3 }\end{array}$ \\
\hline $\begin{array}{l}\text { Definiálható immundeficientia- } \\
\text { szindrómák }\end{array}$ & $\begin{array}{l}\text { DKC1, NBN, STAT3, TYK2, } \\
\text { WAS, WIPF1 }\end{array}$ \\
\hline Antitestdeficientiák & $\begin{array}{l}\text { AID, BTK, CD } 40 L G, \text { ICOS, } \\
\text { IGHM, TACI, UNG }\end{array}$ \\
\hline $\begin{array}{l}\text { T- és B-sejt-defektusokért felelős, } \\
\text { máshol nem szereplő gének }\end{array}$ & LRBA \\
\hline Phagocytafunkció & $\begin{array}{l}\text { CYBB, CSF3R, ELANE, GFI, } \\
\text { G6PC3, HAX1, IFNGR1, } \\
\text { IFNGR2, IL12B, IL12RB1, } \\
\text { SBDS }\end{array}$ \\
\hline $\begin{array}{l}\text { Az immunrendszer szabályozási } \\
\text { zavaráért felelős egyéb gének }\end{array}$ & $\begin{array}{l}\text { AIRE, FAS, FASLG, FOXP3, } \\
\text { PRF1, SH2D1A, XIAP }\end{array}$ \\
\hline $\begin{array}{l}\text { Az NADPH-oxidáz enzimrend- } \\
\text { szer komponensei }\end{array}$ & $\mathrm{NCF} 1 / 2, \mathrm{CYBA}, \mathrm{CYBB}$ \\
\hline $\begin{array}{l}\text { A mikrobiomot szabályozó } \\
\text { gének }\end{array}$ & FUT2 \\
\hline $\begin{array}{l}\text { A cytoskeleton organizációjáért } \\
\text { felelős gének }\end{array}$ & TTC7, IKBKG \\
\hline
\end{tabular}

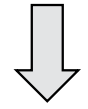

A teljes exom/teljes genom szekvenálása

Az epigenetikai változások azonosítása (DNS-metilációs mintázat, hisztonkód, nemkódoló RNS-ek expressziós szintje)

AID = aktivációindukált deamináz; AIRE = „autoimmun regulátor”; BTK = Bruton-féle tirozin-kináz; CARD9 = kaszpáztoborzó domént tartalmazó fehérje-9; CSF3R = kolóniastimuláló faktor-3-receptor; CXCR4 = CXC-motívumot tartalmazó kemokinreceptor-4; CYBA = citokróm-b-alfa; CYBB = citokróm-b-béta; $\mathrm{DKCl}=$ diszkerin-pszeudouridin-szintáz-1; FASLG = Fas-ligand; ELANE = neutrophil által termelt elasztáz; FOXP3 = „forkhead box” P3 protein; FUT2 = fukoziltranszferáz-2; G6PC3 = glükóz-6-foszfatáz 3-as katalitikus alegysége; GFI = növekedési faktortól független; HAXI = haemopoeticus sejtre specifikus lizinszubsztráthoz asszociált fehérje X-1; ICOS = indukálható T-sejt-kostimulátor; IFNGR = interferon-gamma-receptor; IGHM = immunglobulin-nehézlánc- $\mu$; IKBKG $=\mathrm{NF} \kappa \mathrm{B}$ (nukleárisfaktor-kappa-B)-kináz-inhibitor; IL12RBI = interleukin-12-receptor $\beta 1$ alegysége; IL17RA = interleukin-17-receptor-A; IRAK4 = interleukin1-receptor asszociált kináz-4; LRBA = lipopoliszacharidreszponzív bézsszerű horgonyfehérje; MyD88 = myeloid differenciációs primer válasz-88; NBN = nibrin; NCF2 = neutrophil cytosolicus faktor-2; NOD2 = nukleotidkötő oligomerizációs domént tartalmazó gén-2; PRFl = perforin-1; SBDS = Shwachman-Bodian-Diamond-szindróma; SH2D1A = SH2-domént tartalmazó fehérje-1A; STAT = jelátvivő és transzkripciós aktivátor; TACI = transzmembránaktiváló és kalciummodulátor ciklofilinligand-közremúködő; TRAF3 = tumornekrózisfaktor-asszociált faktor-3; TRIM22 = ,tripartite” motívumot tartalmazó gén-22; TTC7 = tetratrikopeptidismétlődéseket tartalmazó domén-7; TYK2 = tirozin-kináz-2; UNG = uracil-DNS-glikoziláz; $\mathrm{XIAP}=\mathrm{X}$-hez kötött apoptózisinhibitor; WAS = Wiscott-Aldrichszindróma; WIPFl = WAS-sal kölcsönható fehérjecsalád l-es tagja tos módon folyamatosan növekszik, és amelynek kialakulásáért genetikai, immunológiai és környezeti tényezők egyaránt felelősek. Kezelésében egyre növekvő számú biológiai terápiás szer áll rendelkezésre.

Összességében elmondható tehát, hogy az IBD-re és gyermekkori formájára, a VEO-IBD-re jellemző géndefektusok és epigenetikai változások lehető legjobb megismerése új távlatokat nyithat a betegség kezelésében, javítva az életminőséget és növelve a várható élettartamot.

Anyagi támogatás: A közlemény anyagi támogatás nélkül készült.

Szerzői munkamegosztás: A szerzők a kézirat elkészítésében azonos mértékben vettek részt. A cikk végleges változatát mindketten elolvasták és jóváhagyták.

Érdekeltségek: A szerzőknek nincsenek érdekeltségeik.

\section{Irodalom}

[1] Thursby E, Juge N. Introduction to the human gut microbiota. Biochem J. 2017; 474: 1823-1836.

[2] Henderson P, Hansen R, Cameron FL, et al. Rising incidence of pediatric inflammatory bowel disease in Scotland. Inflamm Bowel Dis. 2012; 18: 999-1005.

[3] Müller KE, Lakatos PL, Arató A, et al. Incidence, Paris classification, and follow-up in a nationwide incident cohort of pediatric patients with inflammatory bowel disease. J Pediatr Gastroenterol Nutr. 2013; 57: 576-582.

[4] Snapper SB. Very-early-onset inflammatory bowel disease. Gastroenterol Hepatol. 2015; 11: 554-556.

[5] Benchimol EI, Bernstein CN, Bitton A, et al. Trends in epidemiology of pediatric inflammatory bowel disease in Canada: distributed network analysis of multiple population-based provincial health administrative databases. Am J Gastroenterol. 2017; 112: 1120-1134.

[6] Benchimol EI, Kaplan GG, Otley AR, et al. Rural and urban residence during early life is associated with risk of inflammatory bowel disease: a population-based inception and birth cohort study. Am J Gastroenterol. 2017; 112: 1412-1422.

[7] Denson LA. The role of the innate and adaptive immune system in pediatric inflammatory bowel disease. Inflamm Bowel Dis. 2013; 19: 2011-2020.

[8] Uhlig HH, Schwerd T, Koletzko S, et al. The diagnostic approach to monogenic very early onset inflammatory bowel disease. Gastroenterology 2014; 147: 990-1007.e3.

[9] Li Q, Lee CH, Peters LA, et al. Variants in TRIM22 that affect NOD2 signaling are associated with very-early-onset inflammatory bowel disease. Gastroenterology 2016; 150: 1196-1207.

[10] Neves JF, Afonso I, Borrego L, et al. Missense mutation of TTC7A mimicking tricho-hepato-enteric (SD/THE) syndrome in a patient with very-early onset inflammatory bowel disease. Eur J Med Genet. 2018; 61: 185-188.

[11] Kalla R, Ventham NT, Kennedy NA, et al. MicroRNAs: new players in IBD. Gut 2015; 64: 504-517.

[12] Boyapati R, Satsangi J, Ho GT. Pathogenesis of Crohn's disease. F1000Prime Rep. 2015; 7: 44.

[13] Iwakura Y, Ishigame H. The IL-23/IL-17 axis in inflammation. J Clin Invest. 2006; 116: 1218-1222. 
[14] Verstockt B, Van Assche G, Vermeire S, et al. Biological therapy targeting the IL-23/IL-17 axis in inflammatory bowel disease. Expert Opin Biol Ther. 2017; 17: 31-47.

[15] Verstockt B, Smith KG, Lee JC. Genome-wide association studies in Crohn's disease: past, present and future. Clin Transl Immunology 2018; 7: el001

[16] Torres J, Mehandru S, Colombel JF, et al. Crohn's disease. Lancet 2017; 389: 1741-1755

[17] El-Matary W, Abej E, Deora V, et al. Impact of fecal calprotectin measurement on decision-making in children with inflammatory bowel disease. Front Pediatr. 2017; 5: 7

[18] MacLellan A, Moore-Connors J, Grant S, et al. The impact of exclusive enteral nutrition (EEN) on the gut microbiome in Crohn's disease: a review. Nutrients 2017; 9: pii: E0447.
[19] Kriván G, Szabó D, Kállay K, et al. Successful autologous haematopoietic stem cell transplantation in severe, therapy-resistant childhood Crohn's disease. Report on the first case in Hungary. [Sikeres autológ haemopoeticus őssejt-transzplantáció gyermekkori, súlyos, terápiarezisztens Crohn-betegségben. Az első hazai beteg esetének ismertetése.] Orv Hetil. 2014; 155: 789-792. [Hungarian]

[20] Gaál Z, Oláh E. MicroRNA-s and their role in malignant hematologic diseases. [Mikro-RNS-ek és szerepük hematológiai malignus betegségekben.] Orv Hetil. 2012; 153: 2051-2059. [Hungarian]

(Gaál Zsuzsanna dr., Debrecen, Nagyerdei krt. 98., 4032 e-mail: Gaal.zsuzsanna@med.unideb.hu)

\section{PÁLYÁZAT}

A Prof. Dr. Romics László Akadémikus Emlékére Alapítvány pályázatot hirdet Magyarországon dolgozó, magyar állampolgárságú, 40 éven aluli orvosok és orvosbiológiai kutatással foglalkozó személyek számára. A nyertes pályázó(k) között 500000 Ft alapítványi adomány kerül kiosztásra.

A pályázat célja: a klinikai gyógyítás vagy orvosi tudományos kutatás területén dolgozók kiemelkedő tudományos tevékenységének elismerése.

Előnyt élveznek azok a pályázók, akik az alapítvány névadójának munkásságát folytatva cardiovascularis és anyagcsere-betegségek területéről nyújtanak be pályázatot.

A pályázat benyújtásának határideje: 2019. január 31. (elbírálásának határideje: 2019. április 30.)

A pályázatot a palyazat@romicsalapitvany.hu e-mail címre pdf formátumban kell benyújtani.

A pályázatot természetes személy, saját nevében, magyar nyelven nyújthatja be, a pályázati anyag ábrák nélkül maximum 15000 leütés (karakter) terjedelmü lehet. A pályázathoz mellékelni kell egy rövid szakmai életrajzot a születési év megjelölésével.

A pályázat benyújtását saját kézzel aláírt és dátummal ellátott levélben kell bejelenteni az alapítvány titkárának címezve (a borítékra írandó cím: dr. Dudás Márta, 1461 Budapest, Pf 62.) könyvelt (ajánlott) küldeményben, mert ezen bejelentés alapján válik hitelessé a pályázat. A pályázatot nyomtatott formában nem kell mellékelni.

Az alapítvány adatairól, működéséről a www.romicsalapitvany.hu honlapon található információ. 